Тогобицька В.Д., докторант ННВЦ НУЦЗУ, м. Харків, ORCID: orcid.org/0000-0002-4642-6117

Tohobytska V., doctoral student of Training Research and Production Center of the National university of civil defence of Ukraine, Kharkiv

\title{
ОСНОВНІ ЧИННИКИ ВПЛИВУ ЦИФРОВІЗАЦІЇ ЕКОНОМІКИ НА СОЦІАЛЬНО-ЕКОНОМІЧНІ СИСТЕМИ
}

\section{MAIN FACTORS OF THE INFLUENCE OF DIGITALIZATION OF THE ECONOMY ON SOCIO-ECONOMIC SYSTEMS}

У статті розглядаються основні напрямки державного регулювання соиіально-економічних систем, кадровий та інтелектуальний потенціал цифорвізаиії, економічні та галузеві аспекти циирровізації регіонів. Даються рекомендації з розвитку соиіально-економічних систем в умовах иифровізації економіки.

Ключові слова: діджиталзачія, сочіально-економічні системи, иифрова економіка, регулювання цифрової економіки.

The article considers the main directions of state regulation of socio-economic systems, personnel and intellectual potential of digitalization, economic and sectoral aspects of digitalization of regions. Recommendations for the development of socioeconomic systems in the context of digitalization of the economy are given.

Keywords: digitalization, socio-economic systems, digital economy, regulation of digital economy.

Постановка проблеми. Гострою дилемою донині залишається стан діджиталізації економіки і суспільства, яка розвивається вже кілька десятиліть. Всупереч деяким заявам політиків, представників ЗМІ і навіть вчених, це не нове явище, яке виникло в 21 столітті. Історія розвитку світових цивілізацій і держав доводить, що поряд з завданнями в регіональному масштабі взаємозв'язок людей і об'єктів, а також їх інтеграція в інтернет створюють принципово нові напрямки діяльності. Як наслідок, на регіональному рівні суспільство стикається з серйозними викликами.

Аналіз останніх досліджень і публікацій Проблема визначення впливу діджиталізації економіки на соціально-економічні системи в країні безпосередньо пов'язана із проблемою доцільності та ступеню впливу втручання держави в соціально-економічні системи. Більшість досліджень у цій області базуються на відомих роботах $[1 ; 3 ; 4]$. 
Постановка завдання. Метою статті є дослідити чинники та умови державного регулювання соціально-економічних систем в умовах цифровізації економіки.

Виклад основного матеріалу. Під впливом цифрових технологій змінюються механізми управління і ринкові бізнес-моделі, трансформуються моделі доданої вартості, знижується важливість посередників в економіці, збільшуються можливості індивідуального підходу у створенні товарів і послуг. Перехід до інтенсивного використання цифрових технологій може мати широкі наслідки для макроекономіки.

Цифрові технології швидко поширилися в багатьох країнах по всьому світу. Однак цифрові дивіденди - більш широкі переваги розвитку і використання цих технологій - відстали. У деяких випадках цифрові технології сприяють зростанню, розширенню можливостей і підвищенню якості продуктів і послуг, але їх кумулятивний вплив нерівномірний і неоднозначний. Для того, щоб мати можливість очікувати повного позитивного ефекту від цифрових технологій, необхідно подолати постійний розрив у цифрових можливостях, особливо в доступі до Інтернету. Однак створення однорідного цифрового простору саме по собі не гарантує переваг його використання. Щоб максимально використовувати цифрову революцію, необхідно працювати над доповненнями - інституційними заходами. Це має включати встановлення правил для забезпечення конкуренції між підприємствами, адаптацію навичок працівників до потреб нової економіки та забезпечення підзвітності [1].

Цифрові технології змінюють спосіб роботи бізнесу, полегшують вирішення проблем, які значною мірою залежать від здатності використовувати інформацію, прогнозувати та співпрацювати. Найбільше постраждають компанії, які покладаються на так званий організаційний капітал. Це компанії, які здійснюють процеси управління людьми і людським капіталом - кваліфіковану робочу силу, прийняття рішень якісного характеру. Такі компанії, як правило, гнучкі і здатні максимізувати переваги цифрових технологій, виявляючи та використовуючи можливості для зростання продажів, реорганізації процесів та ефективності виробництва.

На нашу думку, напрямок впливу цифрових технологій може бути використаний як структурна основа системи оцінки від впливу на соціальноекономічну систему. Області реалізації можуть формувати другий вимір в системі оцінки, надаючи йому матричний формат. На вплив цифрових технологій впливають окремі економічні суб'єкти, більш складні структури, виділені промисловістю (традиційною) та/або регіональною (територіальною) основою, національною економікою в цілому, яка визначає рівні, для яких слід встановлювати оцінки [3].

Сучасний рівень розвитку цифрових технологій дозволяє проводити процеси збору, обробки та доставки на місці основної й отриманої інформа- 
ції, з мінімальним відволікаючою кількістю трудових, матеріальних та фінансових ресурсів до цих функцій.

Стрімкий розвиток цифрових технологій призвів до значних змін у всіх сферах суспільства, зберігаючи при цьому високий потенціал для подальших змін. Діджиталізація так чи інакше впливає на більшість людських взаємодій, а соціальні та економічні інститути, частково, намагаються адаптуватися до цих впливів. Жодна галузь не залишається непідвласною до змін, наслідки діджиталізації відчуваються в приватному секторі, в державному секторі, в галузях, які до цих пір не мали впливу з боку технологій, таких як культура.

Виникає питання чи означає діджиталізація, що роботи закінчаться робочими місцями для людини, або процес створення робочих місць буде відбуватися паралельно з процесом усунення робочих місць?

Великий обсяг досліджень зараз присвячений вивченню, поясненню i розумінню технологічних змін, які відбулися в минулому. Необхідно визначити, що з досвіду і результатів можна застосувати в цифровій економіці. Це дасть можливість більш реалістично оцінити його потенціал і перспективи, зрозуміти проблеми і запобігти їх руйнівним наслідкам, своєчасно виявити та використовувати можливості. У цифровій економіці існує широкий розрив між академічною наукою та аналітикою [4].

Тема Четвертої промислової революції стала головною темою 46-го Всесвітнього економічного форуму в Давосі в 2016 році, в якому взяли участь представники близько 140 країн. Президент форуму К. Шваб, піднімаючи питання впливу нових технологій на промислове виробництво та економічний розвиток, відзначив важливість розуміння того, як технології змінюють загальну соціально-економічну структуру на довгострокову перспективу в глобальному масштабі. У різних країнах світу впроваджуються стратегії «Індустрія 4.0» та «Інтернет». У 2009 році в США була прийнята Ініціатива хмарної стратегії, в 2010 році Свропейський Союз прийняв ініціативу Digital Europe, спрямовану на формування інтернет-економіки, в 2011 році Німеччина ініціювала стратегію «Індустрія 4.0» про перехід на «інтернетизоване виробництво», в Китаї в 2015 році прийняли концепцію «нтернет» на основі «розумного виробництва». Четверта промислова революція являє собою якісно новий етап у розвитку технологій і технологій, заснованих на інформації, діджиталізації, а також використанні інтелектуальних систем в промислових процесах, зі значним зниженням людського фактора. У широкому сенсі четверта промислова революція - це нинішня тенденція розвитку, новий рівень організації суспільного життя, економічних відносин, виробництво соціально-економічного розвитку всіх країн.

Наукові видання вважають, що результати будуть залежати від політичних заходів у вирішальній мірі. Політики та інші зацікавлені в розумінні можливостей і викликів діджиталізації повинні бути в курсі якісно нових 
ефектів, що виникають в цифровій економіці. Діджиталізація є однією 3 ключових тенденцій, що впливає на світову економіку, i, здається, немає нічого неминучого в ії впливі на благополуччя в найближчі роки. Результати залежатимуть від вибору інституцій та їх здатності адаптуватися до технологій, демографії, глобалізації та інших факторів, від того, наскільки добре інституції готові до викликів [5].

Масштабні зміни очевидні: населення старіє, а державний борг і безробіття були дуже високими 3 часів фінансової кризи. Це означає, що наслідки соціального благополуччя, пов'язані з неправильним вибором політики або відмовою від вибору, можуть бути особливо згубними і мати довгострокові соціальні та економічні наслідки. Можливий економічний вплив на зростання продуктивності праці, зайнятість та нерівність у доходах можна проілюструвати за допомогою сценарію підходу, і результати будуть рішуче залежати від політичних заходів. Якщо буде прийнята інша форма уваги до протекціонізму, нерівність і безробіття можуть зрости. Буде необхідність зменшити диспропорцію в доступі до соціального забезпечення між співробітниками компанії і самозайнятими.

У минулому економіка змогла адаптуватися до великих змін, перейшовши від переважаючого зосередження уваги на сільському господарстві до зосередження на масовому виробництві та зростанні послуг. Ці зміни збільшили самопочуття всього суспільства, але життя багатьох людей погіршилося й супроводжувалося потрясіннями. Сучасні мережі та стандарти соціального забезпечення пом'якшують тягар змін для окремих осіб, а також розробляють способи розподілу ризиків між групами та поколіннями. Серед країн ОЕСР Японія може бути єдиною, в якій молоде покоління живе не краще, ніж старше покоління, через низьку бідність і швидко старіюче населення в поєднанні з сильними інсайдерськими правами.

Прихильники погляду на діджиталізацію як на процес, аналоги якого можна вважати минулими перетвореннями, які базувалися на технологічних змінах, прогнозуючи зміни в працевлаштуванні, висували наступні аргументи:

1) робочі місця не зникли, незважаючи на величезні зміни в технологіях, які перетворили економіку з сільськогосподарської на промислову та сервісну галузі;

2) комплементарність людей і машин працювати більш продуктивно, а не замінювати людську працю не слід недооцінювати;

3) автомобілі, парова машина, електрика, чиста вода, телефони були більш руйнівними для способу життя, але покращували якість життя більш помітно, ніж цифрові інновації;

4) значна інерція інституцій та регулювання, повільні темпи сприйняття можуть протидіяти новим бізнес-моделям;

5) Інтернет речей i Big Data мають багато елементів правової невизначеності, які затримують їх впровадження та відповідний прибуток; 
6) у ряді сфер взаємодії з людьми споживачеві краще, наприклад, в школах, лікарнях [2].

Використання смартфонів і планшетів стало повсюдним. Тепер ринок готовий до угод 3 цифровими товарами і послугами. Зміни в основному орієнтовані на споживачів. Споживачі шукають в Інтернеті, використовують смартфони для обміну інформацією, фотографіями та досвідом, більшість контактів мають наслідки для комерції або соціального дискурсу. Наступне покоління, швидше за все, все частіше використовуватиме цифрові інструменти для споживання та відпочинку. Це означає, що активізація споживчої спрямованості залишиться головною силою, i iї важливість зросте. Цього достатньо, щоб нова послуга стала доступною принаймні в одному з основних магазинів додатків та/або Інтернету, щоб охопити велику кількість споживачів.

Найкращим порівнянням діджиталізації з більш ранніми технологічними проривами може бути порівняння з впровадженням електроенергії, яка також стала універсальною технологічною основою, що дозволяє використовувати безліч різних машин. Відмінність від електроенергії полягає в тому, що цифрові технології можуть більш-менш послідовно порушувати бізнес - розширюючи сферу застосування і прокладаючи шлях для сучасних застосувань і виробництв, після чого подальші кроки можуть бути більш еволюційними, ніж революційними. Деякі дослідники стверджують, що цифрові технології є єдиною універсальною технологією, яка забезпечує все більший вплив на масштаби [1].

Діджиталізація посилює необхідність інституційних реформ. Завдання полягає в підтримці елементів, які сприяють стабільності, не стримують зростання та інновацій. Діджиталізація дає багато нових способів уникнути негнучких норм і обійти правила, які були вжиті протягом багатьох років. Багато 3 цих правил були прийняті в хороших цілях, особливо для захисту прав споживачів, але значна їх кількість служить для захисту інсайдерів і захисту монополій від конкуренції. Це призводить до підвищення цін для споживачів і ускладнює молодим людям і безробітним отримання робочих місць.

Здається малоймовірним, що діджиталізація означатиме масове безробіття, коли роботи займають велику кількість або навіть більшість робочих місць. Але деякі дослідники, відомі вчені і бізнесмени, такі як фізик Стівен Хокінг; Співзасновник Microsoft Білл Гейтс вважає, що роботи замінять людську працю у величезних масштабах, що по суті означає усунення робочих місць.

Різні погляди на діджиталізацію призводять до певної неоднозначності. 3 одного боку, людям пропонують працювати довше, затримуючи вихід на пенсію, і багато країн, включаючи країни ОЕСР, включаючи Німеччину та Швецію, відчувають дефіцит кваліфікованої робочої сили. Якби роботам 
дійсно довелося взяти на себе більшу частину роботи замість людей, що здається малоймовірним, існуючі способи фінансування добробуту населення не були б застосовані. Велика частина доходів держави генерується за допомогою оподаткування робочої сили. Якщо робочі місця продовжать існувати, робоче життя доведеться продовжити для фінансування багатства, оскільки кількість молодих людей працездатного віку нижче, ніж на пенсії.

Висновки. Підбиваючи підсумки аналізу, можна зробити ряд висновків про вплив діджиталізації на соціально-економічні системи:

- діджиталізація має сильні мережеві ефекти, тому що багато витрат на маржу цифрових послуг низькі або нульові. Витрати на транзакції можуть бути значно зменшені. Цифрові знання не є ексклюзивними та вільно поширюються;

- технології можуть змінити спосіб поширення ризику по всій економіці, ще більше розширюючи розрив між інсайдерами та аутсайдерами, провідними та новачками;

- основний урок економічної історії полягає в тому, що нові робочі місця постійно розвиваються. Проблема полягає в тому, що погані політичні реакції на проблеми діджиталізації можуть ускладнити перехідний період, а період коригування може призвести до зростання структурного безробіття та зростання нерівності.

Спостерігається довгострокова тенденція старіння населення, яка націлена на фінансування добробуту населення, потенційно стикається з розвитком технологій. Проблему неможливо вирішити без суттєвих інституційних змін. Демографічні показники та проблема неузгодження на ринку праці посилюють стимули до автоматизації. Зміни в економіці забезпечать більшу гнучкість на ринку праці та посилення конкуренції за робочу силу.

Розвиток економіки базується на розумінні стимулів і компромісів між різними виборами та їх наслідками для економічної активності та благополуччя. Діджиталізація не впливає на цю базову позицію, але зачіпає багато аспектів економіки. Деякі дослідники вважають, що діджиталізація приносить багато основних припущень, на яких теоретичні економічні моделі побудовані в реальність, роблячи конкурентні моделі, а також миттєву і безпроблемну діяльність з очищення ринку більш актуальною, ніж раніше. Фактично, діджиталізація передбачає більшу ефективність у ряді вимірів. Однак, коли економічні моделі наближаються до реального світу, а точніше, коли реальний світ наближається до ідеалізованих економічних моделей, деякі минулі ситуації та ставлення можуть вимагати переоцінки.

\section{Список використаних джерел:}

1. Антонюк В. П., Шамілева Л.Л. Оцінка ефективності використання трудового потенціалу промисловості з урахуванням рівня наукоємності ії галузей. Економічний вісник Донбасу. 2017. № 2 (48). С. 196-206. 
2. Людський розвиток в Україні: соціальні та демографічні чинники модернізації національної економіки (колективна монографія) / [Е. М. Лібанова, О. В. Макарова, І. О. Курило та ін.]; за ред. Е.М. Лібанової. Київ: Ін-т демографії та соціальних досліджень ім. М.В. Птухи НАН України. 2012. 320 с.

3. Ляшенко B.I., Вишневський О.С. Цифрова модернізація економіки України як можливість проривного розвитку: монографія. Київ: НАН України, Інт економіки пром-сті, 2018. 252 с.

4. Шлапак А. Майбутне української молоді. STEM-освіта. Хвиля. URL:https://hvylya.net/analytics/ maybutnye-ukrayinskoyi-molodi-osvita.html

5. Україна 2030Е - країна з розвинутою цифровою економікою / Український інститут майбутнього. URL: https://strategy.uifuture.org/kraina-zrozvinutoyu-cifrovoyuekonomikoyu.html\#6-2-1.

\section{Reference:}

1. Antoniuk V. P., Shamileva L.L. Otsinka efektyvnosti vykorystannia trudovoho potentsialu promyslovosti z urakhuvanniam rivnia naukoiemnosti yii haluzei. Ekonomichnyi visnyk Donbasu. 2017. № 2 (48). S. 196-206.

2. Liudskyi rozvytok v Ukraini: sotsialni ta demohrafichni chynnyky modernizatsii natsionalnoi ekonomiky (kolektyvna monohrafiia) / [E. M. Libanova, O. V. Makarova, I. O. Kurylo ta in.]; za red. E.M. Libanovoi. Kyiv: In-t demohrafii ta sotsialnykh doslidzhen im. M.V. Ptukhy NAN Ukrainy. 2012. 320 c.

3. Liashenko V.I., Vyshnevskyi O.S. Tsyfrova modernizatsiia ekonomiky Ukrainy yak mozhlyvist proryvnoho rozvytku: monohrafiia. Kyiv: NAN Ukrainy, In-t ekonomiky prom-sti, 2018. 252 s. 10.

4. Shlapak A. Maibutnie ukrainskoi molodi. STEM-osvita. Khvylia. URL: https://hvylya.net/analytics/ maybutnye-ukrayinskoyi-molodi-osvita.html.

5. Ukraina 2030E - kraina z rozvynutoiu tsyfrovoiu ekonomikoiu / Ukrainskyi instytut maibutnoho. URL: https://strategy.uifuture.org/kraina-z-rozvinutoyucifrovoyuekonomikoyu.html\#6-2-1. 